\title{
Project EASTMAR: planning of an aeromagnetic survey off East Greenland
}

\author{
H. C. Larsen and L. Thorning
}

Project EASTMAR, an aeromagnetic survey of major parts of the continental margin off East Greenland, is an energy research project funded by the Danish state through the Energy Agency (Thorning, 1978). The aim of the project, which started in 1977, is to map the shelf on a regional basis with a special emphasis on the delineation of the possible hydrocarbon potential. In 1978 the main work has been the logistical preparations, the compilation of existing data and the negotiations with commercial companies interested in the airborne operations of 1979.

The compilation of existing data includes aeromagnetic data from Larsen 1975 (in Larsen, 1978), regional surveys carried out by various U.S. Navy agencies (Johnson et al., 1975a; Phillips et al., 1973), and marine seismic data. Through the compilation the geological understanding of major parts of the shelf has developed to the stage of working hypotheses. The available bathymetric data have been compiled into five new offshore maps (scale 1:1 000 000, Larsen, 1979). A major effort has gone into writing the computer programmes (Thorning, 1977) used in the interfacing of aeromagnetic data from various sources. At the same time new programmes for compilation and interpretation have been added. In this work GGU has had valuable assistance from the Danish consultants, Geokon ApS.

Negotiations with about 10 commercial geophysical companies started in early 1978 and were concluded in November with the signing of a contract with Aero Service Division, Western Geophysical Company of America. In these negotiations GGU was assisted by Aqua-Terra Consultants of Calgary, Canada.

The survey operations which are to start in March/April 1979 will use a specially equipped long range DC-3 aircraft. A second back-up aircraft (long range Cessna Titan) is available during the survey period. The aircraft will carry a high resolution total field magnetometer in a towed bird configuration. Navigation will primarily rely on two LTN $56-$ Inertial Navigation Systems integrated with a Doppler system. A stand alone Loran-C system and coastal ties will supply additional navigational data.

The preliminary flight line programme is shown in fig. 32. Priority has been given to a complete regional coverage of all areas on the East Greenland continental margin between $60^{\circ}$ and $77^{\circ} \mathrm{N}$ which may contain potential petroleum accumulations. It is intended to tie the flight plan onto continental basement on the western side and to the oceanic basement on the eastern side of the primary survey area. Margin areas without coverage shown on the flight line map (mainly between $68^{\circ}$ and $70^{\circ} \mathrm{N}$ and on the outer shelf $72^{\circ}-77^{\circ} \mathrm{N}$ ), have already been surveyed. As one of these surveys (Phillips et al., 1973) includes major parts of the outer shelf north of $77^{\circ} \mathrm{N}$, some traverses have been scheduled on the inner shelf between $77^{\circ}$ and $80^{\circ} \mathrm{N}$.

\section{Geological background to flight plan}

The southern and central part of area $1 S$ contains Tertiary and probably pre-Tertiary reflectors with several seconds of thickness (Featherstone et al., 1977; Johnson et al., 1975a, 
Fig. 32. Preliminary flight line map showing subblock division (heavy black line), sceduled traverses (black line) and tie lines (broken line). The flight lines shown on this map total 65000 line $\mathrm{km}(1 \mathrm{~S}: 25370 ; 1 \mathrm{~N}: 25030$; 2: 4860; 3S: 1420; 3M: 1660 ; $3 \mathrm{~N}: 570 ; 4: 1920 ; 5: 3270$ and profiles I, II: 900 ).

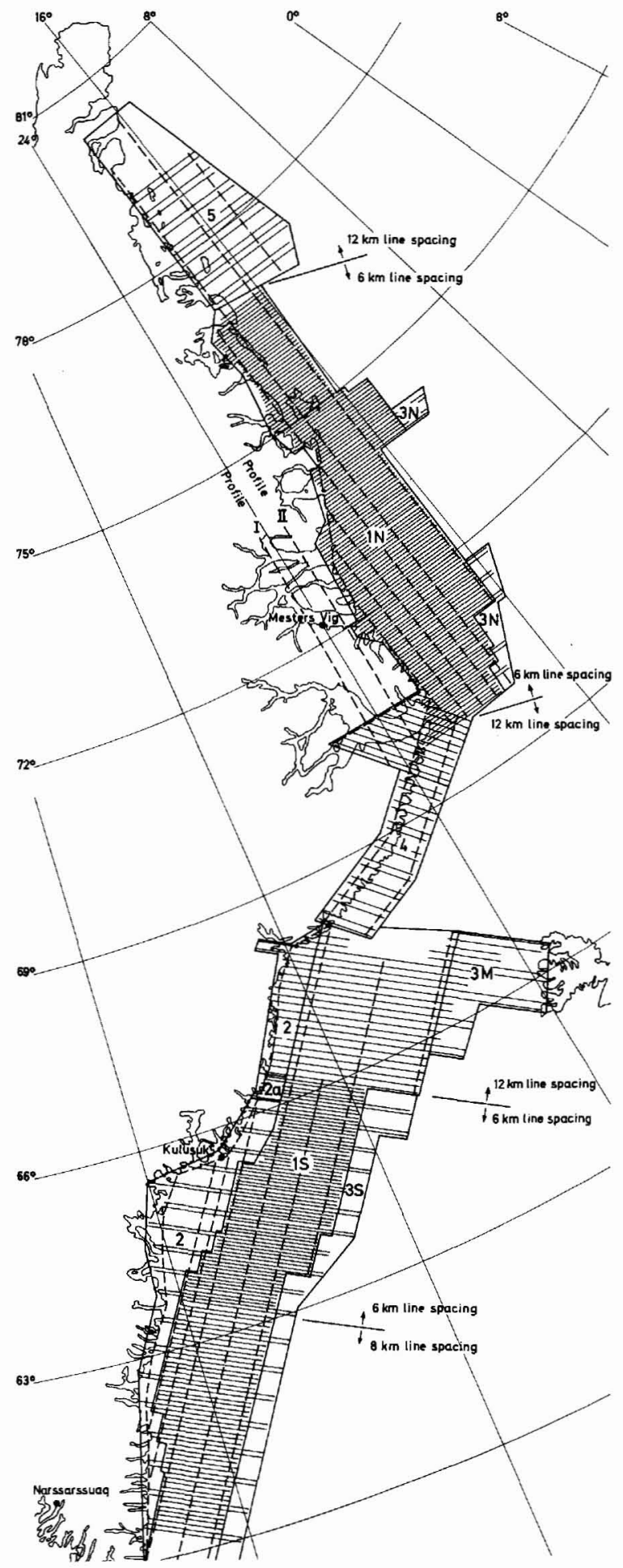


b; Vema Cruise 27, 28, 1974 and unpublished data). Depth to magnetic basement is reported (H. C. Larsen, 1975) to reach $3 \mathrm{~km}$ in the middle of the area whereas in the northern part major sedimentary sequences seem to be restricted to rather small graben or half graben structures (Johnson et al., 1975a; Vema Cruise, 27, 28, 1974, and unpublished data). These sedimentary remnants seem to constitute the southern extension of a major basin situated to the north $\left(68^{\circ} \mathrm{N}\right.$, Johnson et al., $1975 \mathrm{a}$; Hinz \& Schlüter, 1978 , and unpublished data). It is likely that major Tertiary volcanism and tectonism have affected this northern part of area 1 S (partly in Larsen, 1978). A $12 \mathrm{~km}$ spacing has been decided in that northern part of area 1 $\mathrm{S}$, whereas, partly depending on water depth, 6 and $8 \mathrm{~km}$ spacing has been applied to the middle and southern part.

Within area 2 and $2 a$ Precambrian basement seems to be continuously exposed (Featherstone et al., 1977; B. Larsen, 1975; H. C. Larsen, 1975, and unpublished data) and in the northern area frequently intersected by Tertiary volcanics (Larsen, 1978). In addition to the navigational accuracy, traverses in area 2 and 2 a will supply information about the magnetic behaviour of the basement rocks and volcanics exposed.

Surveying in area $3 S$ and $3 M$ serves the purpose of an accurate and valid mapping of the continent to ocean transition and the oldest Tertiary sea floor spreading anomalies (mainly no 24, Talwani \& Eldholm, 1977).

Considerable amounts of geophysical data (Johnson et al., 1975a; Talwani \& Eldholm, 1977; Hinz \& Schlüter, 1978, and unpublished data) show that a large basin containing sediments of Tertiary and in part also pre-Tertiary age exists offshore area 4 . A well known Mesozoic basin is situated north of area 4 (Surlyk, 1978). The onshore part of area 4 is mainly built up of early Tertiary volcanics. The planned survey in area 4 adjoins surveys previously undertaken to the north and east (Johnson et al., 1975a; H. C. Larsen, 1975) and should focus on the relationship between (1) the volcanics and associated Tertiary tectonism and (2) the adjoining sedimentary basins, especially the possible offshore extension of the volcanics.

Area $1 N$ adjoins two previous surveys (H. C. Larsen, 1975; Phillips et al., 1973). Boundaries have been drawn in accordance with the previous coverage and the general aim of tieing the flight plan to known basement exposures, either continental or oceanic. Both onshore geological and geophysical data (Birkelund \& Perch-Nielsen, 1976; Henderson, 1976; H. C. Larsen, 1975; Surlyk, 1978) and offshore geophysical data (Hinz \& Schlüter, 1978; Johnson et al., 1975a; Eldholm \& Windisch, 1974; Vema Cruise 27, 28, 1974, and unpublished data) stress the possible petroleum potential of area $1 \mathrm{~N}$. It is most likely that the area contains several fault bounded basins comprising sedimentary rocks with an age range from the upper Palaeozoic or even older to the upper Mesozoic, the basins at least locally being capped by a very thick blanket of Tertiary clastic sediments (Hinz \& Schlüter, 1978).

Surveying in area $3 \mathrm{~N}$ serves the same purpose as in area $3 \mathrm{~S}$ and $3 \mathrm{M}$, and will fill in gaps in existing data.

Expectations to area 5 are almost identical to those of area $1 \mathrm{~N}$ concerning regional geology, but logistic and budgetary limitations do not allow a complete coverage of this area.

\section{References}

Birkelund, T. \& Perch-Nielsen, K. 1976: Late Palaeozoic evolution of central East Greenland. In 
Escher, A. \& Watt, W. S. (edit.) Geology of Greenland, 304-339. Copenhagen: Geol. Surv. Greenland.

Eldholm, O. \& Windisch, C. C. 1974: Sediment distribution in the Norwegian - Greenland Sea. Bull. geol. Soc. Amer. 85, 1661-1676.

Featherstone, P. S., Bott, M. H. P. \& Peacock, J. H. 1977: Structure of the continental margin of South-Eastern Greenland. Geophys. J. R. astr. Soc. 48, 15-29.

Henderson, G. 1976: Petroleum geology. In Escher, A. \& Watt, W. S. (edit.) Geology of Greenland, 488-506. Copenhagen: Geol. Surv. Greenland.

Hinz, K. \& Schlüter, H. U. 1978: Der Nordatlantik - Ergebnisse geophysikalischer Untersuchungen der Bundesanstalt für Geowissenschaften und Rohstoffe an nordatlantischen Kontinentalrändern Erdöl Erdgas Z. 94, 271-280.

Johnson, G. L., McMillan, N. J. \& Egloff, J. 1975a: East Greenland continental margin. In Yorath, C. J. Parker, E. R. \& Glass, D. J. (edit.) Canadas Continental Margin and offshore Petroleum Exploration. Can. Soc. petrol. geol. Mem. 5, 205-244.

Johnson, G. L., Sommerhoff, G. \& Egloff, J. 1975b: Structure and morphology of the West Reykjanes Basin and the south-east Greenland continental margin. Mar. Geol. 18, 175-196.

Larsen, B. 1975: Marine geophysical survey of the East Greenland shelf south of Angmagssalik. Rapp. Grønlands geol. Unders. 75, 87-88.

Larsen, H. C. 1975: Aeromagnetic investigations in East Greenland. Rapp. Grønlands geol. Unders. 75, 88-91.

Larsen, H. C. 1978: Offshore continuation of East Greenland dyke swarm and North Atlantic Ocean formation. Nature 274, 220-223.

Larsen, H. C. 1979: New bathymetric maps of the East Greenland continental margin. Internal GGU-report (in prep.)

Phillips, J. D., Fleming, H. S. \& Feden, R. H. 1973: Aeromagnetic study of the Greenland and Norwegian seas. Abs. geol. Soc. Amer. 5, 767.

Surlyk, F. 1978: Jurassic basin evolution of East Greenland. Nature 274, 130-133.

Talwani, M. \& Eldholm, O. 1977: Evolution of the Norwegian-Greenland Sea. Bull. geol. Soc. Amer. 88, 969-999.

Thorning, L. 1977: A brief description of the computer programs used by GGU in the treatment of aeromagnetic data. Rapp. Grønlands geol. Unders. 85, 37-45.

Thorning, L. 1978: Project EASTMAR: a new aeromagnetic survey of the continental shelf of eastern Greenland. Rapp. Grønlands geol. Unders. 90, 113-115.

Vema Cruise 27, 28, 1974: Underway Marine Geophysical Data in the North Atlantic June 1961 January 1971, Part F: Seismic Reflection Profiles. In Talwani, M. (edit.) Lamont-Doherty Survey of the World Ocean, 293 pp.

\section{$\mathrm{Rb}-\mathrm{Sr}$ isochron ages from east Milne Land, Scoresby Sund, East Greenland}

\section{B. T. Hansen and H. Tembusch}

A prominent NNE-SSW trending fault in central Scoresby Sund, separates the eastern part of Milne Land geologically from the rest of the island. This east Milne Land fault block, comprises metasediments bounded by a variety of post-kinematic intrusions in which three 